УДК 821.161.2 Франко : [37.016:82]+37.02]/477.83/.86)"185/19"

DOI:

Володимир Микитюк, кандидат філологічних наук, дочент кафедри української літератури імені Михайла Возняка Львівського начіонального університету імені Івана Франка

\title{
ПОЗАПРОГРАМНА ПЕДАГОГІЧНА ДІЯЛЬНІСТЬ ІВАНА ФРАНКА
}

У статті розглянуто позапрограмну педагогічну діяльність I. Франка в контексті історії начіональної освіти, його конщептуальні ідеї щодо навчання літератури у середній і вищій школі. Показано трансформацію філософсько-педагогічних поглядів вченого від філантропізму і позитивізму до прагматизму, діахронно проаналізовано і структуровано форми і способи дидактичної взаємодії Франка-педагога, методологію дидактичного впливу на найширші верстви украӥнського соиіуму в Галичині у 2-й пол. 19-го - поч. 20-го сторіччя.

Ключові слова: Іван Франко; історія педагогіки; навчання літератури; форми і методи дидактичноі взаємодї

Jim. 10.

Volodymyr Mykytyuk, Ph.D.(Philology), Associate Professor of the Ukrainian Literature Department named after Mykhaylo Voznyak Lviv Ivan Franko National University

\section{EXTRACURRICULAR PEDAGOGICALACTIVITY OF IVAN FRANKO}

In the article the extracurricular pedagogical activity of Ivan Franko in the context of the history of national education and his conceptual ideas concerning the teaching of literature in the secondary and high school are considered. The methodology of the educational practices of that time and the main features of the author's methodology of the teacher, confirmed by didactic results, samples, examples of his scientific and creative work are explored. The article emphasizes the expediency of the studying of the development history of the curriculum, the updating of the methodology of its study in the context of the introduction of Ukrainian pedagogy to the Bologna educational process; there is accented on the need to reduce the existing curricula for Ukrainian literature in the secondary and high school. It is proved that the historical experience of the European scientist is still not sufficiently absorbed; therefore, the analysis and systematization of non-institutional educational activities of the coryphaeus of Ukrainian science should take the proper place in the history of pedagogics.

The study proposes to consider the pedagogical heritage of Ivan Franko exclusively diachronically, in development, together with the newest Franko-studies in the field of philosophy, political science, and studies of literature. On the material of Ivan Franko's works on history and theory of pedagogics, artistic texts with educational themes and problems the non-institutional pedagogical discourse of Ivan Franko, the forms and methods of his pedagogical communication with the broadest strata of Ukrainian society are systematized and analysed. The evolutionary path of the scientist from the simplest forms of influence on peers to complex the author's methodological concepts of teaching and education is shown: in accordance with the basic postulate of the pedagogics of pragmatism, I. Franko particularly emphasized that the school science is only the first stage of preparation for all further independent life, that the main task of the teacher in his communication with the wards at school and outside the school is to teach them to think creatively, prepare them for self-education, independent and critical mastering of knowledge.

The article represents the transformation of the philosophic-pedagogical views of the scientist from philanthropy and positivism to pragmatism, diachronically analyses and structures the forms and methods of the didactic interaction of Franko-teacher, the methodology of didactic influence on the broadest strata of Ukrainian society in Halychyna in the 2nd half of the 19th-the beginning of the 20th century.

Keywords: Ivan Franko; history of pedagogics; teaching of the literature; the forms and methods of didactic interaction.

П

остановка проблеми. Педагогічна теорія ніколи не постає “сама в собі”, завжди є вираженням певного ширшого, як правило, загального філософського погляду на світ, становить його своєрідну екземпліфікацію через з'ясування і засвоєння методології багатьох прикладів попередніх освітніх практик, окремих авторських методик, підтвердження дидактичними результатами, зразками, прикладами. Вивчення історії розвитку курікулуму, методології його дослідження надзвичайно актуальне для української педагогіки, адже входження до Болонського освітнього процесу потребує титанічної роботи особливо у цій площині. Наприклад, чинні програми навчання з української літератури у середній і 
вищій школі потребують кардинального i системного оновлення, а історичний досвід європейського вченого ще достатньо не засвоєний. Предметом пошуку цієї розвідки є головно позапрограмна педагогічна діяльність Франка, що зумовили політичні та суспільні чинники його часу. Національна педагогіка та літературознавство надзвичайно багато втратили від того, що Франко не посів у свій час кафедру української словесності Львівського університету. Прочитавши в альма матер лише знану габілітаційну лекцію, він став вчителем всієї нації, реалізовував свої дидактичні концепції у художній творчості, науковій роботі, публіцистиці та громадському житті. Аналіз і систематизація позаінституційної освітньої діяльності корифея української науки має посісти належне місце в історії європейської педагогіки.

Аналіз останніх досліджень і публікацій. Різні аспекти педагогічного доробку Івана Франка так чи так досліджували багато істориків освіти і літературознавців. Варто відзначити праці науковців, які залучали доробок класика для аналізу різноманітних проблем сучасної освіти. Це Г. Васянович, 3. Гузар, I. Денисюк (педагогічне франкознавство); О. Невмержицька (аксіологія освіти); Г. Токмань (екзистенційно-діалогічне навчання української літератури); М. Чепіль (I. Франко про національне та естетичне виховання у школі); Т. Пастух (генологія Франкових текстів); А. Ситченко (концепції і технології літературного аналізу ушколі); А. Скоць, Б. Тихолоз, Н. Тихолоз, Р. Чопик (Франкові принципи аналізу тексту), М. Ільницький, Л. Каневська, Г. Клочек, І. Набитович, М. Нечиталюк, Л. Скупейко, Є. Пшеничний, Г. Сабат (сучасні проблеми методичного освоєння спадщини I. Франка) та ін. Незважаючи на те, що є чимало праць, присвячених вивченню окремих аспектів педагогічного спадку I. Франка, існує необхідність докладнішого розгляду саме його позапрограмної діяльності, що особливо важливо в умовах розвитку громадянського суспільства в Україні.

Метою статті. Систематизація та аналіз позаінституційного педагогічного дискурсу Івана Франка, форм і методів його педагогічної комунікації в соціумі.

Виклад основного матеріалу дослідження. Розглядаючи педагогічну спадщину I. Франка, помилковим буде сприйняття ії як константи, як щось стале, незмінне, “єдиноправильне”. Тільки діахронно, урозвитку, врешті так, як цю проблему вирішило літературознавство: 1) творча методологія I. Франка формувалась еволюційно упродовж усього життя письменника; 2) ранній
Франко перебував під впливом романтичноідеалістичного спрямування літератури; 3) захоплення філософією позитивізму зумовило реалістичний тип творчості; 4) в ідейно-естетичних пошуках митець часто випереджав й визначав розвиток національної літератури; 5) визначальною рисою художнього методу I. Франка була здатність синтезувати; 6) засвоєння інтернаціональних естетичних канонів у творчості Франка мало характер інтеграційного взаємозбагачення $[1,77]$. Ці постулати $є$ характеристичними і щодо педагогічного дискурсу мислителя, котрий не можна розглядати окремо від загального інтелектуального мейнстриму Франка. Не менш продуктивною для нашого ракурсу освоєння спадщини мислителя є періодизація еволюції його світоглядних позицій: 1) До першого арешту у 1877 р. Світогляд молодого Франка формувався на народних побутових засадах, вихідним принципом яких є соціальна справедливість; 2) 1878 - поч. 1880-х років. Пошуки розв'язання соціальних проблем на основі соціалістичних ідей, сформульованих під впливом марксизму й лассалівства, але не тотожних марксизмові; 3) друга пол. 1880-х років - перша пол. 1890-х. Дуалізм світогляду - боротьба соціального й національного, спроба розв' язати ці проблеми на основі критичного підходу до марксизму..; 4) 3 другої пол. 1890-х років. Чітка позиція щодо розв'язання соціальних питань через створення національної держави. . . Ревізія марксизму і показ його неспроможності і в теоретичній, і в практичній площинах [9, $101-123]$.

Як неординарна особистість, ще 3 дитячих років Франко прагнув мати вплив на довколишніх, формувати коло своїх однодумців. Уже своєю “інакшістю” від однолітків “малий Мирон” здобував право на окремий шлях у житті, відхід від традиційного у тих умовах вибору продовження батьківської стежки. Історикфранкознавець слушно резюмує цю тему: "Посвоєму Франко узагальнив досвід частини інтелігенції сільського походження, таких “дивовижних появ”, як він сам. Потреба психологічної компенсації за свою “іншість” штовхала їх на самоствердження через розвиток своїх інтелектуальних здібностей у школі чи самоосвітою, навчанням гри на музичних інструментах, залученням у релігійні справи тощо. Щоб закладений у такій дитині потенціал міг зреалізуватися, потрібен був сприятливий збіг обставин, що перетворив би шанс на життєву реальність" $[2,74]$. Чи не обов'язковою рисою характеру визначного педагога має бути прагнення лідерства, бажання бути першим у 
навчанні, літературних і наукових спробах, незалежність й оригінальність мислення, критицизм стосовно наявного стану речей, відвага і здатність іти всупереч, за словами самого Франка - “проти рожна перти”. В його особистості це були домінантні складові із раннього дитинства, звідти - блискучі успіхи унавчанні вслід за певним “заціпенінням" після зіткнення із шкільним догматизмом та схоластикою, постійна самоосвіта і дуже інтенсивне як на школяра, а потім гімназиста, репетиторство. У гімназії через репетиторство Франко реалізовував свої педагогічні амбіції: він утверджувався у реальності планів самому стати гімназійним чи університетським учителем. Це і було його життєвою мрією, планом на життя, допоки письменницька i, головно, - політична діяльність не перекреслила їх. Попри його жорстку, максималістську критику “урядження” освітою та справді низького методичного і наукового рівня тодішньої школи, Франко зустрів у своєму житті справжніх педагогів і під їхнім впливом вже 3 гімназійної лавки готувався до викладацької кар'єри.

Його значна, як на той час, бібліотека формувалась великою мірою, особливо у гімназії, за репетиторські послуги: “Я діставав книжки переважно від товаришів за те, що помагав їм у шкільних заняттях, а дещо купував за гроші, зароблені також із лекцій (приватні уроки - В. М.) і ощаджені на їді та одежі" [6, 320]. Розуміння значення книгозбірень, глибокий аналіз структури, вад, але й незамінних достоїнств, які несуть для освіти (особливо гуманітарної) бібліотеки, засвідчують ще зовсім ранні Франкові студентські статті 1878 року (“Допис про Дрогобицьку гімназію”, “Ученицька бібліотека у Дрогобичі"), чи пізніші “Ревізія шкільних бібліотек”, "Педагогічні невігласи”, “Конечність реформи учення руської літератури по наших середніх школах" та десятки інших. Особливо чітко і конкретно згадує Франко про своє раннє “бібліофільство” у спогадах, написаних 1903 року під назвою “Гірчичне зерно”. “...Від п’ятого гімназіального, прочитавши припадком драми Шекспіра та Шіллера, я набрав замилування до книжок і почав збирати свою власну бібліотеку, яка до кінця моїх гімназіальних часів виросла до числа 500 томів. Ся бібліотека, в якій, крім різних класичних авторів, було зібрано немало й таких книжок, яких не було в гімназіальній бібліотеці або яких годі було дістати 3 неї, зробилась центром невеличкої громадки учеників, яка, не маючи ані характеру, ані форми ніякого товариства й ніякої організації, час від часу сходилася на читання та на розмову" [6, 318 - 319]. Представлено приклад ще однієї форми впливу та комунікації (крім книгозбірні) на соціум - співацький хор. I то не будь-де, а на природі, де пісня особливо прониклива й органічна, дозволяє пізнати кожну людину у всій глибині і неповторності. Хрестоматійно відомим $є$ вислів Гете: "Природа - єдина книга, кожна сторінка якої наповнена глибоким змістом”. Франкова пристрасть до пленеру, його природовідчування були дуже глибокими, показовою для нього була педагогічна практика його гімназійного вчителя у Дрогобичі Івана Верхратського, який організовував регулярні виїзди чи, точніше, навчальні виходи на лоно природи. Також пожиттєве хобі Франка - рибалка і збирання грибів, - 3 часом стали і засобом педагогічного впливу як на своїх дітей, так і на багатьох знайомих.

Зрілий Франко доволі активно заперечував проти прямого зіставлення його літературних героїв з ним самим, однак такі паралелі часто неминучі. Іван Денисюк переконливо писав про таку автобіографічність: “Ця широка амплітуда енциклопедизму гімназиста, ця академія Міхонського і його учень-вундеркінд не надумані. Їх прототипами були дрогобицька гімназія і сам автор оповідання "Борис Граб", хоч Франко зі скромності відхрещувався від автобіографізму” $[3,180]$. У ракурсі дослідження варто подивитись ширше щодо експлікації письменницького “я” на образи надзвичайно цінного з педагогічної точки зору оповідання "Борис Граб”, яке постало як окремий текст унаслідок того, що белетрист не завершив роман "Не спитавши броду”. Власне, у цьому "романі виховання" чи не більш автобіографічним є образ Антонія Трацького, а насправді обидва герої відтворюють дві частини особистості митця: його образне і понятійне світосприйняття, його емоціо і раціо, аполлонівське та діонісіївське начало. Франко у художньому тексті “зіштовхує” у численних педагогічних діалогах власні сумніви, з’ясовує ті питання, які хвилювали його на різних етапах життєвого шляху. Загальновідомою є ціложиттєва Франкова драма боротьби із власними “романтичними скоками" (вислів М. Драгоманова), придушення, “притлумлення”, правдива “війна” із самим собою за право написання текстів емоційних, за тодішніми визначеннями - ідеалістичних, його “смеркальний” жаль за “ненародженими дітьмитворами”, що ними він пожертвував, змушений виконувати важку “каменярську” роботу. Описана у романі лектура текстів, через які герой пізнавав літературу, це великою мірою авторів шлях, зокрема захоплення поезією Ніколая Ленау, про 


\section{ПОЗАПРОГРАМНА ПЕДАГОГІЧНА ДІЯЛЬНІСТЬ ІВАНА ФРАНКА}

що амбівалентний Франко писав: “Але поезія Ленау, то не сонний романтизм; є в ній доволі й різких, мужеських нот, що не дають чоловікові забутися і розплистися в мряці сонних мар" [7, 330]. Подібний дуалізм поцінування естетичних й ідейних якостей словесного мистецтва бачимо і в образі Густі Трацької, а подано це через призму бачення практичного, реального і не “склонного до поезіі” Бориса.

Таким чином, Франків “роман виховання" вказує на декілька важливих форм впливу на учнів, методологічних концептів навчання i виховання. Зокрема, мислитель постійно наголошував на тому, що шкільна наука є лише першим етапом підготовки до всього подальшого самостійного життя, що головне завдання учителя у його спілкуванні з підопічними у школі і поза школою “научити мізком рушити”, приготувати їх до самоосвіти, самостійного i критичного засвоєння знань. Цивілізаційна сутність Франка-вченого, Франка-педагога не викликає сумнівів, адже визначальною у його світогляді була центральна проблема будь-якого світосприйняття - свобода людини, шлях до демократії як форми життєвої спільноти, що ціхувало також еволюційний шлях мислителя до педагогіки прагматизму: Франкова концепція людини у 1890 - 1900-х роках уже не містить детермінізму буття особистості, не визнає індивідуума објєктом і жертвою обставин. Хоча, з іншого боку, людина теж не $\epsilon$ абсолютно вільною, не $\epsilon$ повним субјєктом, однак за нею залишається право оцінювання дійсності і вибору, зумовленого відповідальністю за реалізований чи не здійснений вчинок. У парадигмі прагматистів не існує абсолютної і незмінної правди, як і не існує “правильних" знань: навчання і пізнання - це лише динамічний шерег процесів, спрямований на формування, “ліплення” особистості. За Франком, неможливо дійти у рецепції художнього тексту до “правильної" відповіді, лишень до “якоїсь”, а здобутий таким чином досвід і знання будуть корисними тільки за межами навчального закладу, в індивідуальному “дорослому” житті. Тобто, бачимо сповідування основних постулатів прагматизму як теорії пізнання, яка передбачала, що справжність і функціональна вартість знань залежить від обставин і місця, особи і часу. Прагматизм приваблював Франка також i світським демократичним індивідуалізмом, i різкою критикою традиційної освіти. Безперечно до педагогіки прагматизму належить непримиренне несприйняття репродуктивного навчання, передусім літературного. Франко стало заперечував підготовку учнів до суспільного життя через “переказування” навчального матеріалу, через “кутє”, засвоєння готових і доконаних знань і відповідей. Звідси - нещадна критика шкільних підручників як конденсованої “мудрості поколінь”, з допомогою яких учителі наповнюють старанних і послушних учнів “правильними” знаннями і моральними приписами. Врешті, наш педагог постійно реалізовував у своїй практиці головне гасло прагматистів про те, що навчання має бути повсякденним і неперервним, освіта $є$ реальним досвідом, натомість школа й університет $\epsilon$ місцями, де триває підготовка до майбутнього, $\mathrm{i}$ триває дійсне життя. Либонь, і сьогодні можемо сказати, що школа в основному звертає увагу на організацію і методику засвоєння учнями якнайбільшої кількості інформації, але ж це є лише першим етапом і суто інструментальною справою, що позбавлена загальнокультурних i педагогічних вартостей.

Співпраця учителя та учня в позаурочний час, формування для підопічного лектури для самостійного читання та вільне обговорення прочитаних текстів, неформальне спілкування під час мандрівок, походів, у літніх таборах, участь у позаурочному шкільному житті, особистий приклад учителя для морального розвитку особистості учня - це лише окремі педагогічні аспекти, що їх виокремлював Франко. Для прикладу, розгляньмо у тезах короткий план формування “зразкового” гімназиста Бориса Граба, що його застосовував Франковий “ідеальний” учитель Міхонський головно в позаурочний час. Уважаючи, що “наука в двох перших гімназійних класах вимагала лише пам'яті, а не праці думок...” [5, 179], Міхонський “....навчив його порядно ходити... навчив тої акуратності й економії у всіх рухах, словах і поступках, що, як він говорив, повинна ціхувати розумного і практичного чоловіка”; “...узявся робити з ним хатню гімнастику”. "Велів Борисові в вільних хвилях учитися столярства” [5, $177-178]$. Навчив “ясного" думання, точності й економії у всіх рухах, поступках, чесного й відвертого поводження 3 учнями й учителями; вимагав критичного i самостійного оцінювання будь-яких джерел, вироблення власної думки про все та праці над собою; заклав основи літературної освіти, “стереометричного” читання текстів, “давав йому читати докладні життєписи даних авторів, збірники їх листів, мемуари їх самих та їх сучасників і тим приучував його, з одного боку, розуміти всякий твір людського на основі того часу й тих живих людських взаємин, яких він був витвором i виразом, a 3 другого боку, 


\section{ПОЗАПРОГРАМНАПЕДАГОГІЧНА ДІЯЛЬНІСТЬ ІВАНА ФРАНКА}

призвичаював розуміти історію даного часу, так сказати, аналітично, із свідоцтв та настроїв тогочасних людей, а не 3 готових шаблонових конструкцій шкільних підручників" $[5,186]$.

Демократичне спілкування, турбота про моральний розвиток учня i, як наслідок, відповідальність учня перед улюбленим вчителем, нешаблонний погляд на історію, мистецтво, суспільство, заснована на власному прикладі виховна методика неодмінно сформують неординарну особистість, - так відчитується образ учителя Міхонського в оповіданні “Борис Граб”. Максималістською була Франкова оцінка відповідальності учителя за учнів, адже він уважав, що педагог зобов'язаний зацікавити, захопити своїх підопічних, наситити інтелектуальне й духовне життя, щоби не залишалось місця для неморальних діянь. Міхонський з оповідання "Борис Граб" ніколи не голосував за виключення із гімназії навіть найбільших “грішників”, бо вбачав у хибах гімназистів свою вину. Алкоголь, карти, розпуста - це або ж приклад нездорового неморального поводження самих вчителів, або ж наслідок того, що навчання $€$ невмотивованим, шаблонним $\mathrm{i}$ схоластичним, відсугнє духовне життя у колективі, - у чому знову ж таки винуватий вчитель. У спогадах "Гірчичне зерно" письменник, окрім згадки про оригінальних та відповідальних педагогів, рельєфно описує ту частину гімназійних вчителів, що поклонялась “культу скляного бога”, забувала про всякі наукові інтереси. Сам Франко, який в одному з хрестоматійних віршів писав про себе “я з п'ющими за пліт не виливаю”, у житті був прикладом стриманого та раціонального вживання алкоголю. Як це не дивно, але, не будучи абсолютним пуританином, уже зрілий і відомий діяч навіть “виховував” за допомогою чарки. Візьмімо, для прикладу, спогади про Франка відомого у національній історії Левка Чикаленка, який приїхав з Полтави у Галичину 1904 року на літні виклади, організовані львівськими науковими колами. Шістнадцятирічний хлопець був захоплений формою і змістом Франкових лекцій 3 історії давньої української літератури, але не менш був вражений і на все життя причарований астральною i, водночас, дуже земною, людяною постаттю знаного митця і науковця. Йдеться про Франкове уміння створювати атмосферу довіри, близькості, педагогічний такт у стосунках із своїми учнями. Промовистим є приклад поїздки юнака (з дозволу мами) із Франком у Нагуєвичі, щоб “побачити галицьке село”, порибалити “з бовтєм" у гірській річці. Така риболовля дуже специфічна і цікава, азартний релакс вразив хлопця, але йдеться про інше: “Виїхали ми зі Львова увечері і вранці вже приїхали до Дрогобича. Хоч і мали ми 3 дому якийсь харч 3 собою, але як тільки вийшли $з$ вагона, Франко, запитавши мене, чи не хочу я часом підкріпитись, повів мене до буфету і там мене, як дорослого, почав розпитувати, що я п'ю. Засоромив він мене тим питанням надзвичайно, а в той же час підніс мене в моїх очах несказанно. Я признався щиро, що рідко що взагалі пив, і не дуже на тім розуміюся. Отож він сам уже замовив щось для себе, а для мене чарку вишнівки і якоїсь там закуски. Одна чарка - а який вплив на мене зробила! Не від алкоголю, а від свідомості, що Франко мене вважає дорослим, я неначе справді виріс. Якось ще вільніше став себе з ним почувати, і взагалі Франко тим мене цілковито залучив до своїх найбільших поклонників” $[8,417]$. Власне, коментар бачимо уже у словах Чикаленка. Особистий приклад дуже помірного вживання алкоголю, розумне обмеження і довіра до юного учня справила на нього безмірно більше виховне значення, ніж фарисейські пуританські заборони і табу, які молодь часто долає не так із бажання і потреби справді “щось” попробувати, як із прагнення здобути “заборонений плід”, самоутвердитись.

Підсумовуючи численну і багатовимірну педагогічну діяльність Івана Франка, ще раз наголосимо на тому факті, що відбулась вона саме як “позакурікулярна”, “позапрограмна”, “позаінституційна" адже життєві перипетії не дали змоги реалізувати безпосередньо у навчальних закладах його інтенції. Не можемо назвати його роботу “позакласною”, адже це прерогатива педагогічного колективу, що здійснює дидактичні і навчальні функції з тими ж учнями в позаурочний час [4, 684 - 685]. Радше це сьогодні дефінюється як “Позашкільна освіта і виховання”, яка “...здобувається громадянами у позаурочний час у позашкільних навчальних закладах та інших навчальних центрах...” [4, 685], однак варто пам'ятати, як зазначає Чеслав Купісєвіч, що "позаурочні заняття можуть заразом мати, але не завжди, характер позашкільних занять, і навпаки. При такому підході позашкільні заняття $\epsilon$ - поруч власне “шкільних" занять - другою істотною організаційною формою процесу навчання-учіння, що доповнює дидактичновиховну діяльність, яка провадиться на уроках" $[10,174]$. У такому методологічному ракурсі педагогічну діяльність Івана Франка більш виправдано класифікувати як позапрограмну, адже тодішній курікулум не передбачав того різноманіття форм і методів дидактичного впливу 
на найширші верстви суспільності, що їх використовував дидакт.

Висновки. Педагогічна спадщина Франка, як і художня продукція, наукова методологія його літературознавчих, фольклористичних, етнографічних, соціологічних таінших досліджень, важкопіддаються рубрикуванню, структуруванню за певними “шухлядками”, адже мислитель часто йшов новаторськими, непротореними стежками, творив свої схеми і системи, а менторські інтенції реалізовував через: 1) репетиторство у школі, гімназії й університеті; 2) збирання бібліотеки, випозичання та обговорення книг, що утверджувало його лідерське інтелектуальне становище; 3 ) участь у хорах, гімназійних і студентських товариствах; 4) індивідуальне та групове спілкування на лоні природи під час численних природничих мандрівок та екскурсій; 5) семінари, лекції на українознавчих курсах для молоді з материкової України за програмами наукового товариства імені Т. Шевченка, відчити у рамках освітніх програм "Просвіти”, виступи на вічах, під час парламентських виборів, пізніше - читання власних текстів перед учасниками різноманітних українських громад і спільнот; 6) безпосереднє спілкування із студентською молоддю на різноманітних зустрічах, ювілеях, спеціальних лекціях. У тому числі і неформальне у кав'ярнях, бібліотеках, редакціях; 7) залучення до наукової праці гімназистів, студентів та вчителів через участь виданнях і видавничих проектах, які курував Франко; 8) участь у написанні й обговоренні літературних портретів, видань художньої спадщини українських письменників-корифеїв, які становили основу шкільної лектури. Напр., Шевченкового видання творів; 9) написання більше ста сорока статей, відгуків та рецензій 3 педагогічною проблематикою, у яких порушував питання історії освіти в Україні, методології і методики навчання, наповнення шкільних й університетських програм з української мови і літератури, навчальних підручників, становища учителя та інших актуальних педагогічних проблем; 10) особистий моральний авторитет, приклад здорового способу життя, поєднання інтелектуальної праці із фізичною, спортом та активним відпочинком; 11) виховання і навчання власних дітей; 12) художні твори, у яких створив цілу галерею образів педагогів і порушував різноманітні проблеми освіти.

Вивчення дидактичного доробку I. Франка далеке до завершення, адже сьогодні стали доступними чимало нових текстів класика європейської освіти, у життєвій простороні якого педагогічна діяльність не була основною цариною, однак зробив він надзвичайно багато i, на жаль, його дидактичні уроки належним чином ще невідзискані. Завдяки ренесансному універсалізмові свого таланту й інтелекту Франко здійснив своєрідний прорив із “рідної тісноти” (вислів Пантелеймона Куліша) на європейські і світові простори, у тому числі і педагогічні, залишившись органічно цілісним у своїх національних почуттях і самосвідомості.

\section{ЛІТЕРАТУРА}

1. Голод Р. Іван Франко та літературні напрями кінця XIX - початку XX століття / Роман Голод. - ІваноФранківськ : Лілея-НВ, 2005. - 284 с.

2. Грицак Я. Пророк у своїй Вітчизні. Франко та його спільнота (1856-1886) / Ярослав Грицак. - К. : Критика, 2006. $-631 \mathrm{c}$

3. Денисюк I. "Не спитавши броду" як роман виховання // Денисюк I. О. Літературознавчі та фольклористичні праці: У 3 томах, 4 книгах. - Львів, 2005. - T. 2. - C.174-191.

4. Енциклопедія освіти. - За ред. В. Кременя. - К., 2008. -1039 c.

5. Франко І. Борис Граб / Іван Франко // Зібрання творів: у 50 т. Т. 18 / Іван Франко. - К.: Наук. думка, 1978. -C. $177-191$.

6. Франко І. Гірчичне зерно (Із моїх споминів) / Іван Франко // Зібрання творів: у 50 т. Т. 21 / Іван Франко. К.: Наук. думка, 1978. - С. 316-332.

7. Франко І. Не спитавши броду / Іван Франко // Зібрання творів: у 50 т. Т. 18 / Іван Франко. - К.: Наук. думка, 1977. - С. 325-463.

8. Чикаленко Левко. Як ми з I. Франком ловили рибу // Спогади про Івана Франка. Упорядник М. Гнатюк. Львів, 1997. - С. 416-418.

9. Якимович Б. 3. Іван Франко - видавець: Книгознавчі та джерелознавчі аспекти / Богдан Якимович. - Львів: ВЦ ЛНУ ім. І. Франка, 2006. -691 с.

10. Czesiaw Kupisiewicz, Dydaktyka ogylna, Wydanie II, Oficyna Wydawnicza Graf-Punkt (Warshawa, 2002), 304 s.

\section{REFERENCES}

1. Holod, R. (2005). Ivan Franko ta literaturni napriamy kintsia XIX - pochatku XX stolittia [Ivan Franko and literary trends of the late XIX and early XX centuries]. Ivano-Frankivsk: Lileia-NV, 284 p. [in Ukrainian].

2. Hrytsak, Ya. (2006). Proroku svoii Vitchyzni. Franko ta yoho spilnota (1856-1886) [The Prophet in his Fatherland. Franko and his community (1856-1886)]. Kyiv: Krytyka, 631 p. [in Ukrainian].

3. Denysiuk, I. (2005). "Nespytavshy brodu" yak roman vykhovannia ["Withoutasking about the ford" as a novel of upbringing]. Literaturoznavchi tafolklorystychni pratsi: $u 3$ t., 4 kn. Lviv: Frankoznavchi doslidzhennia, pp. 174-191. [in Ukrainian].

4. Kremen, V. H. (2008). Entsyklopediia osvity [Encyclopedia of Education]. Kyiv: Yurinkom Inter, 1039 p. [in Ukrainian]. 
5. Franko, I. (1978). Hirchychne zerno (Iz moikh spomyniv) [Mustard Seed (Frommy remembrances)]. Zibrannia tvoriv: u 50 t. Vol. 21. Kyiv: Nauk. dumka, pp. 316-332. [in Ukrainian].

6. Franko, I. (1977). Nespytavshy brodu [Withoutasking about the ford]. Zibrannia tvoriv : u $50 \mathrm{t}$. Vol. 18. Kyiv: Nauk. dumka, pp. 325-463. [in Ukrainian].

7. Franko, I. (1977). Ne spytavshy brodu [Without asking the wade]. Zibrannia tvoriv: u 50 t. Vol. 18. Kyiv: Nauk. dumka, pp. 325-463. [in Ukrainian].

8. Chykalenko Levko. Yakmy z I. Frankom lovyly rybu
[Howweand I. Franko werefishing]. Spohady pro Ivana Franka [Memoirs about Ivan Franko]. (Ed.). M. Hnatiuk. Lviv, pp. 416-418. [in Ukrainian].

9. Iakymovych, B. Z. (2006). Ivan Franko-vydavets: Knyhoznavchi ta dzhereloznavchi aspekty [Ivan Franko - publisher: Bibliography and source criticism aspects]. Lviv, $691 \mathrm{p}$. [in Ukrainian]

10. Czesiaw Kupisiewicz, Dydaktyka ogylna, Wydanie II,Oficyna Wydawnicza Graf-Punkt(Warshawa, 2002), 304 s [in Polish].

Стаття надійшла до редакції 16.05.2018

УДК 37.013 .42

DOI:

Ася Сучану, кандидат педагогічних наук, викладач кафедри сочіальної роботи, сочіальної педагогіки та фізичної культури Ізмаїльського державного гуманітарного університету

\section{СВОСРІДНІСТЬ ПРОЦЕСУ СОЩАЛІЗАЦІЇ ЯК СОЦАЛЬНО-ПЕДАГОГІЧНИЙ ФЕНОМЕН}

У статті розглянуто генезис статусу процесу соиіалізаиї̈ та процесу виховання у сучасній психологопедагогічній науці; визначено вплив "сочіального середовища" як сукупності умов співіснування людини $i$ суспільства; розкрито зміст сфер існування людини, де відбувається засвоєння соціальних зв 'язків, а саме: діяльність, спілкування і самосвідомість; проаналізовано сочіальні ролі, які виконує та чи інша особистість у суспільстві, а також відповідні стадії прочесу сочіалізаиії; визначено та з 'ясовано роль основних факторів, через які проходять етапи соиіалізаиії особистості; доведено значення стратегії соиіальної адаптації.

Ключові слова: сочіалізація; соціальне середовище; соціальна адаптація; особистість; соціальна стратегія.

Jim. 6.

Asya Suchanu, Ph.D.(Pedagogy), Lecturer of the Social work, Social Pedagogy and Physical Culture Department Izmayil State Humanitarian University

\section{PECULIARITY OFTHE SOCIALIZATION PROCESS AS A SOCIALAND PEDAGOGICAL PHENOMENON}

The object of the modern psychological and pedagogical research is not only the study of the characteristics of the psychological evolution of the individual, but also the measurement of temporary evolution, differentiated by changes that take place throughout life, from birth to death, with a tendency closer to a particular social role. The article deals with the significant contribution to the study of this area brought researchers in the field of age psychology. It should be noted that in the domestic psychological tradition there were controversies over the accuracy of the definition, which means "the process of social formation of the individual through factors, factor and social roles", using the phrase "development of personality". We tried to cover the controversial issue of the non-identity of the two terms "development of personality" and "socialization of personality", since it is a polar vision of the essence of one and the same process. We were asked to consider the term "education" in the narrow and broad sense, where the definition of the purposeful process is carried out by a specific person (narrow understanding of the definition), and the process of socialization opposes in the broad sense, since it refers not only to the agents of education, but the system of life of the individual and the relations that take place in one's environment. Based on the analysis of reference sources, we considered the main areas of human existence as a subject of socialization (activity, communication, self-consciousness). In addition, for the social formation of man as a social component of modern society, the social environment, which covers the moment of human birth and ends with its life, is the obligatory condition of the above-mentioned process. Inside the content of the "social environment" we considered the factors that necessarily pass the stages of socialization of the individual and, accordingly, the stages of formation of the subject of social society are distinguished. Conceptual is that according to each stage there are also such institutions of socialization, where the process of formation of the personality continues: the family, pre-school establishments, schools, labor collective, institute after labor (various clubs of interests, the environment of peers, etc.). 